\title{
Determination of The Melting Points of Organic Compounds Making Use of $\beta$-Ray Backscattering
}

\author{
Sigeaki MATsumoto and Hisanobu KOBAYASHI \\ Faculty of Engineering, Saitama University \\ Urawa, Saitama \\ Received August 4, 1976
}

\begin{abstract}
A new method of determining the melting points was devised using the principle that the $\beta$-rays backscattered by the organic compounds placed on the heated metal disk increase rapidly at the melting point because the scattering area of the compounds becomes small by the effect of capillary action in the melting and the metal disk surface covered with the compounds is partly exposed. Carbon-14 and platinum plate were used as the $\beta$-ray source and the disk, respectively. The measured melting points of powdered azobenzene, sulfanilamide, dicyandiamide and phenolphthalein agreed with the correct melting points within an accuracy of $\pm 2^{\circ} \mathrm{C}$. The quantities of sample necessary for measurements are about $1 \mathrm{mg}$. This method is free from error due to visual observation and is also free from the $\beta$-ray source contamination.
\end{abstract}

\section{Introduction}

In order to eliminate the error due to visual observation, the melting points of powdered crystals have been determined by using a radioactive $\alpha$-source by $\mathrm{H}$. Kobayash ${ }^{11}$. This method is based on the principle that a sudden increase of $\alpha$-ray absorption is caused by the melting of powdered crystals because the liquid spread out over the source so that a larger area were covered than when the crystals were present.

Furthermore, the automatic measuring apparatus of the melting points in this method has been developed by K. Nakai, et $\mathrm{a}^{2}{ }^{2}$. The melting points from room temperature to $400^{\circ} \mathrm{C}$ can be determined with this apparatus. Nevertheless, this method has two disadvantages. One is the danger of $\alpha$-source contamination because powdered crystals are directly placed on the $\alpha$ source. The other is that the disturbance of ionization currents due to the variation of air density by heating is so large. To avoid this disturbance, a gentle breeze always must flow through a gap between the heated disk and the $\alpha$-source.

Also, a method of determining the dew- point making use of $\beta$-ray scattering has previously been devised by the authors ${ }^{3}$. In the present method, the same $\beta$-ray source as above devised is used. The principle and experimental results of the new method are described.

\section{Principle}

The backscattered $\beta$-rays increase with the increase of atomic number of the scatterer. When the heated metal disk having large atomic number is covered over with an organic compound which consists of elements of small atomic number, the counting rate of $\beta$-rays backscattered by the compound is smaller than that backscattered by the disk. When the temperature of the disk is gradually raised to the melting point, some particles of compound begin to melt and become into the liquid and the other particles which do not melt soak up the liquid by the effect of capillary action. As a result of the soaking in the capillary action, the surface of the disk covered with the particles before the melting is partly exposed because the liquid is removed. This causes an increase in the counting rate of $\beta$-rays backscattered at the 
melting point. Thus, the melting point of organic compounds are measured by a sudden increase in the backscattered $\beta$-rays at the melting point.

It is desired that the quantity of measured sample is as small as possible in the measurements so that the counting rate of $\beta$-rays backscattered will rapidly increase at the melting point. The low energy of $\beta$ ray source is required to fulfill above conditions because the small quantity of sample should be placed in the saturation thickness for $\beta$-ray backscattering.

\section{Experimental apparatus}

The experimental apparatus is schematically shown in Fig. 1. It consists of a $\beta$ ray source, a Geiger-Müller counter, a heated metal disk and a heater. Carbon-14 is used as the $\beta$-ray source because it has low energy and is sealed in the hollow of a small plastic lump, $3.5 \mathrm{~mm}$ in diameter and $1.5 \mathrm{~mm}$ thickness, which is attached to the center of the cross-fiber in front of the counter window.

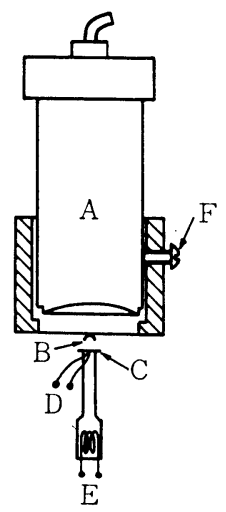

Fig. 1 Schematic diagram of the experimental apparatus. A: Geiger-Müller counter, B: $\beta$-ray source, C: Heated metal disk, D: Thermocouple, E: Heater, F: Screw

The direct $\beta$-rays from the source are prevented from entering into the counter by this lump. The counter which has a mica window of $1.4 \mathrm{mg} / \mathrm{cm}^{2}$ thickness and $25 \mathrm{~mm}$ in diameter is affixed to the cylinder by screws. Therefore, both the source and the counter window face on the disk. The distance between the counter and the source and between the disk and the source are adjusted to the optimum condition by screws. The above two distances are $7.5 \mathrm{~mm}$ and 4 $\mathrm{mm}$, respectively. It is desirable that the disk is of anticorrosive nature and has a large atomic number. To do so, the circular platinum plate, $5 \mathrm{~mm}$ in diameter and $0.2 \mathrm{~mm}$ in thickness, is used as shown in Fig. 4(a). The disk could be heated up to $300^{\circ} \mathrm{C}$ by the small 6 watt heater and the temperature of the disk is measured by a thermocouple. Then, the counting rate of the backscattered $\beta$-rays and the temperature are recorded simultaneously against the time.

The increase of the backscattered $\beta$-rays due to the rising temperatures of the disk is shown in Fig. 2. For temperatures up to $300^{\circ} \mathrm{C}$ from room temperature, the counting rate increased by 18 percent. However, the increase is about 0.6 percent per ten degrees so that it can be practically neglected in the determination of the melting points. The time constant of the counting rate meter fixed at $30 \mathrm{sec}$ in the experiment.

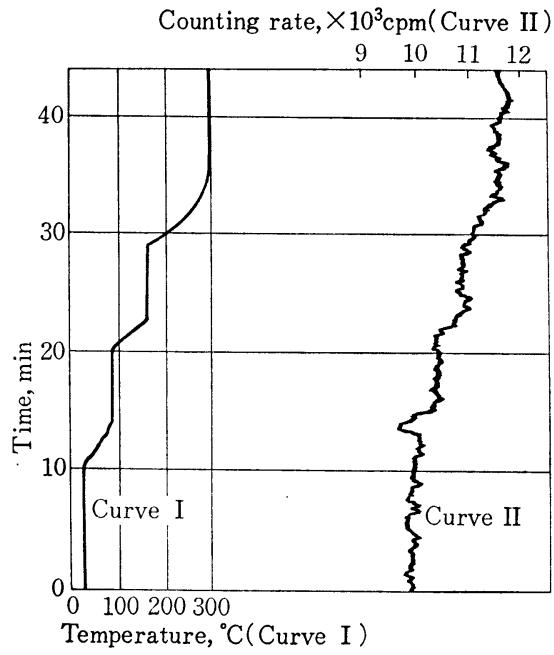

Fig. 2 The increase of the backscattered $\beta$ rays due to the rising temperatures of the heated disk. The counting rate of the backscattered $\beta$-rays and the temperatures are recorded against the time. The counting rate increases by 18 percent for temperatures up to $300^{\circ} \mathrm{C}$. 


\section{Experimental results}

Four standard organic compound samples for measurements of the melting points, namely, azobenzene ( $\left.\mathrm{mp} 68.4-69.0^{\circ} \mathrm{C}\right)$, sulfanilamide ( $\mathrm{mp} 165.6-166.1^{\circ} \mathrm{C}$ ), dicyandiamide (mp 209.5-209.9 ${ }^{\circ} \mathrm{C}$ ) and phenolphthalein ( $\mathrm{mp}$ $261.4-261.9^{\circ} \mathrm{C}$ ) were prepared in the experiments. The powdered compound was uniformly placed on the disk in a layer that was as thin as possible, as shown in Fig. 4(b). The temperature was raised slowly at the rate of two or three tenth degrees per minute near the melting point.

The experimental result of azobenzene is shown in Fig. 3. The counting rate was $9800 \mathrm{cpm}$ before sample be placed on the disk. When $0.5 \mathrm{mg}$ of powdered azobenzene was placed on the disk, the counting rate decreased to $7700 \mathrm{cpm}$ and maintained this value near the melting point. Then, when the temperature reached the melting point, the counting rate began to increase and reached to $9000 \mathrm{cpm}$.

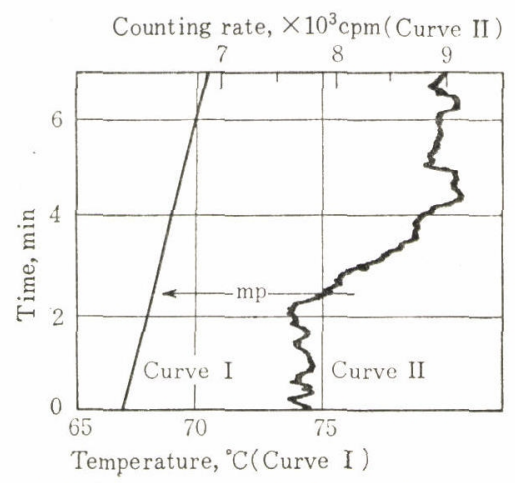

Fig. 3 Measurement of the melting point of azobenzene. The counting rate increases rapidly at $68.3^{\circ} \mathrm{C}(\mathrm{mp})$.

This phenomenon was clearly observed with a microscope as shown in Fig. 4. At the melting point, some particles of azobenzene became liquid and the layer of the other particles which were not yet melted soaked up the liquid by capillary action as shown in Fig. 4(c). The surface of the disk which was covered with the particles before the melting was partly exposed. In Fig. 4(d), the exposed area of the disk surface is kept to be the same as shown in

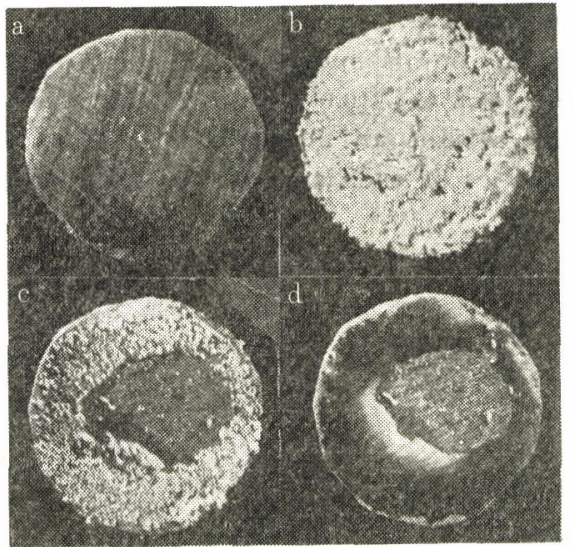

Fig. 4 Photographs of the melting of azobenzene. (a) The heated disk of platinum, $5 \mathrm{~mm}$ in diameter and $0.2 \mathrm{~mm}$ in thickness. (b) Before the melting point, $0.5 \mathrm{mg}$ of azobenzene is uniformly placed on the disk. (c) At the melting point, particles which are not yet melted soaked up the liquid by capillary action and the surface of the disk is partly exposed. (d) All particles have been melted at $69 \cdot 3^{\circ} \mathrm{C}$.

Fig. 4(c) when all particles have been melted. After the temperature became a little higher than the melting point, it was slowly dropped to the freezing point. The counting rate maintained the constant value of $9000 \mathrm{cpm}$ after the melting. The melting point measured in Fig. 3 was $68.3^{\circ} \mathrm{C}$ and was decided when the counting rate increased by twice the standard deviation $( \pm 90 \mathrm{cpm})$

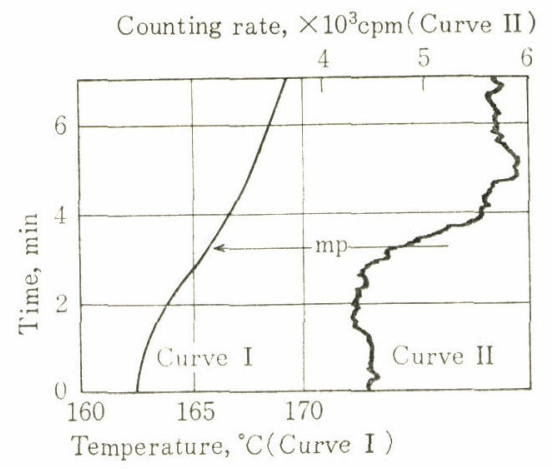

Fig. 5 Measurement of the melting point of sulfanilamide. The counting rate increases at $165.8^{\circ} \mathrm{C}$.

Experimental results for sulfanilamide, dicyandiamide and phenolphthalein are 
shown in Fig. 5, 6 and 7, respectively. The melting points measured in these figures were $165.8^{\circ} \mathrm{C}, 210.0^{\circ} \mathrm{C}$ and $261.7^{\circ} \mathrm{C}$, respectively within an accuracy of $\pm 2^{\circ} \mathrm{C}$. The quantities of each sample was about $1 \mathrm{mg}$.
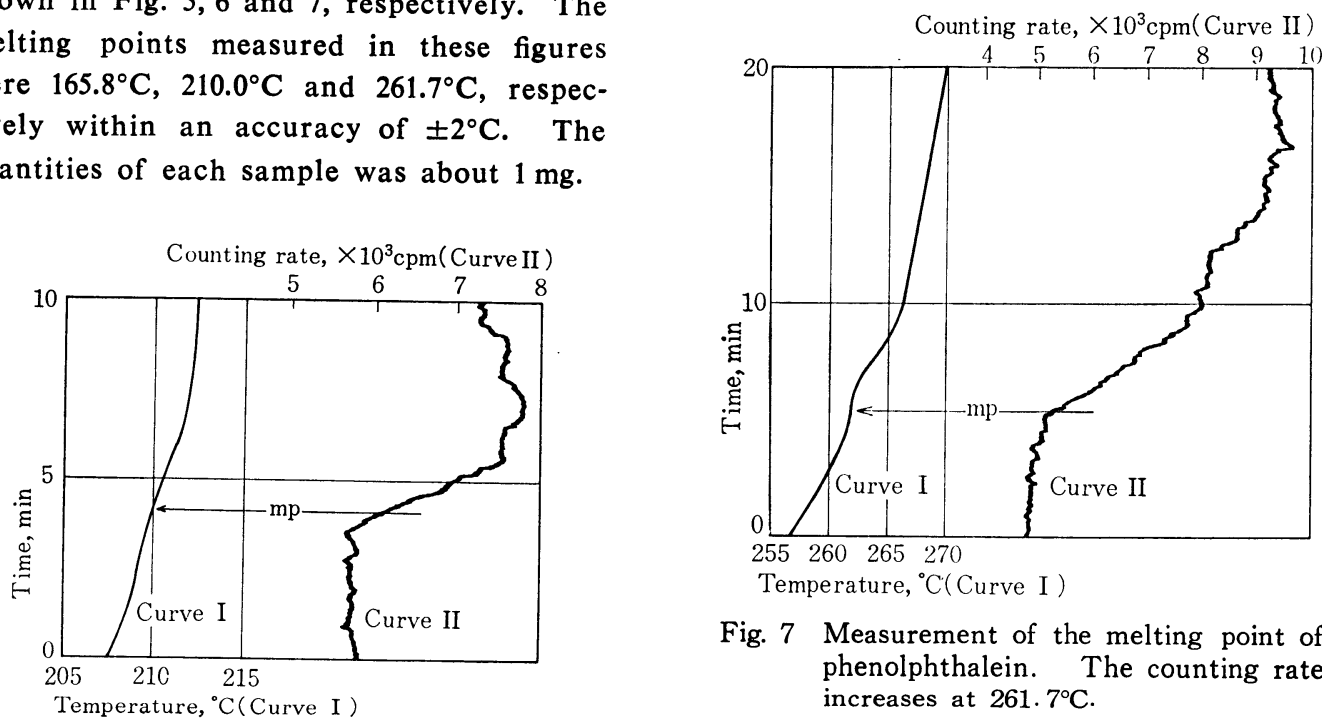

Fig. 7 Measurement of the melting point of phenolphthalein. The counting rate increases at $261.7^{\circ} \mathrm{C}$.

\title{
References
}

Fig. 6 Measurement of the melting point of dicyandiamide. The counting rate increases at $210.0^{\circ} \mathrm{C}$.

This new method is free from the error due to visual observation and also from $\beta$ ray source contamination because the $\beta$-ray source are completely separated from the sample.

1) H. Kobayashi: Sci. Papers Inst. Chem. Res., 59, 1 (1965)

2) K. Nakai, H. Omori, E. Goto and M. Koyama: Sci. Papers Inst. Phys. Chem. Res., 50, 39 (1974)

3) H. Kobayashi: Rev. Sci. Instr., 42, 397 (1971); H. Kobayashi, S. Matsumoto, M. Yamanouchi and S. Toyohka: Radioisotopes, 20, 655 (1971)

\section{要旨}

\section{$\beta$ 線散乱を利用した有機化合物の融点測定}

\author{
松本茂昭, 小林久信 \\ 埼玉大学工学部 \\ 浦和市下大久保 255
}

\begin{abstract}
この測定は，加熱される高い原子番号の金属円板上に薄く一様に散布された低い原子番号の元素 からなる有機化合物の粉体が融点に扣いて局部的に融けて毛細管現象で粉末にしみ込むことによっ て, 金属板の一部表面が露出するため $\beta$ 線の後方散乱計数率が增加することを利用している。 $\beta$ 線

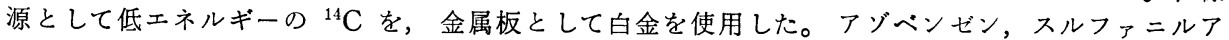
ミド, シシシアンジアミド,フェノールフタレインの融点 $260^{\circ} \mathrm{C}$ まで標沎試料について測定し士 2 ${ }^{\circ} \mathrm{C}$ 精度で正しい值が得られた。この測定に要する試料は $1 \mathrm{mg}$ 程度である。この方法では肉眼観 察に上る誤差を除くことができまた放射線污染の危険がない。
\end{abstract}

